\title{
Modelling present and future global distributions of razor clams (Bivalvia: Solenidae)
}

\author{
Hanieh Saeedi ${ }^{*}$, Zeenatul Basher and Mark J. Costello
}

\begin{abstract}
Razor clams (Pharidae and Solenidae) are deep-burrowing bivalves that inhabit shallow waters of the tropical, subtropical, and temperate seas. Using 'maximum entropy', a species distribution modelling software, we predicted the most suitable environments for the entire family and 14 Solen species to indicate their present and future geographic distributions. Distance to land, depth, and sea surface temperature (SST) were the most important environmental variables in training and creating the present and future distribution models both at the family and species level. In the present distribution models at the family level, the most suitable environment was where distance to land was between 0 and $100 \mathrm{~km}$, a depth of 0-150 m, wave height of 5-7 m, a mean chlorophyll-a concentration about $0.7 \mathrm{mg} \mathrm{m}^{-3}$, and mean SST between 12 and $28^{\circ} \mathrm{C}$. Comparison with the future distribution models at the species level, found that most species were predicted to shift their distribution ranges poleward under the future environmental scenarios; i.e. species in the northern hemisphere would shift northward and southern species southward. Models also predicted that half of the species would expand their distribution ranges, $29 \%$ of species would not change their distribution, and $21 \%$ of species would shrink their distribution ranges under future climate change. Expanding geographic ranges would result in overlap in species ranges and thus greater species richness at regional scales. Model results predict that the mid-latitude peaks of species richness will move further apart, increasing the dip in richness near the equator, due to global climate change.
\end{abstract}

Keywords: Species distribution modelling, MaxEnt, Climate change, Range shifts, Mollusca, Ocean Biogeographic Information System, Global Biodiversity Information Facility

\section{Background}

Global climate change will influence the future distributions of marine species [1,2]. Distribution maps indicating future suitable environments can predict the possible range shift of benthic species as a response to increasing temperatures $[1,3,4]$. Species are likely to respond to climate warming by shifting their distributions poleward [2, 5]. Predictive suitable environmental modelling is widely used to identify the environmental factors that control organisms' distribution and predict their geographic range from reported locations [3, 6-10].

One of the most ecologically and economically important superfamilies of marine Bivalvia is Solenoidea which

\footnotetext{
*Correspondence: hanieh.saeedi@auckland.ac.nz; hanieh.saeedi@gmail. com

Institute of Marine Science, University of Auckland, Auckland 1142, New Zealand
}

(c) The Authors 2016. This article is distributed under the terms of the Creative Commons Attribution 4.0 International License (http://creativecommons.org/licenses/by/4.0/), which permits unrestricted use, distribution, and reproduction in any medium, provided you give appropriate credit to the original author(s) and the source, provide a link to the Creative Commons license, and indicate if changes were made. as razor clams [11-13]. In an ecological context, razor clams' contributions to trophic food webs include serving as prey to crabs, gastropods, sea birds, and demersal fish $[14,15]$. In some countries such as Iran, some species of razor clams (e.g., Solen dactylus) are being harvested by the local fishermen as bait for fishing and/or shrimp aquaculture $[12,16]$.

The family Solenidae has two genera, Solen Linnaeus, 1758 (65 accepted species) and Solena Mörch, 1853 (2 accepted species) with long narrow shells. Solenidae are deep-burrowing bivalves which dig to about $30 \mathrm{~cm}$ depth in low intertidal and subtidal sediments $[11,13,16]$. They have free-swimming larvae and may grow $20-30 \mathrm{~mm}$ per year [12]. Solenidae are mostly distributed in subtidal zones down to about $100 \mathrm{~m}$ in the tropical and temperate seas along the Indo-Pacific and Indian Ocean, east and north-west Pacific, European Atlantic coasts, western 
south Atlantic Ocean, and north and south American coasts. They are absent from the polar regions in both the southern and northern hemispheres. The tropical Indo-Pacific area contains the highest number of species (about $75-80 \%$ of all known species) [11, 17].

Despite their wide distribution and ecological importance, limited sampling and ease of mis-identification (due to subtle morphological differences between species) contribute to gaps in knowledge of Solenidae global distribution patterns $[15,18,19]$. Environmental modelling may provide a better indication of the actual geographic distribution than reported locations alone, and can enable predictions of the effects of climate change.

Saeedi et al. (in press) found that the latitudinal gradient of species richness in razor clams was asymmetric and bimodal, with more species in the northern hemisphere and a dip between $0^{\circ}$ and $-15^{\circ}$ latitude. Chaudhary et al. (2016) found this was typical for marine taxa, so razor clams may be a good model taxon for other marine species' biogeography [20]. Indeed, the biogeography of razor clams species' endemicity matched well that of marine species overall [21]. This study predicts the global distribution of the Solenidae family and 14 species based on environmental variables. We then test the hypothesis that species distributions would shift polewards from their present distributions under future climate change. Thus, our findings may be applicable to a wide range of marine taxa.

\section{Methods}

\section{Geographic distribution}

Data on species geographic distributions were gathered from the Global Biodiversity Information Facility (GBIF), Ocean Biogeographic Information System (OBIS), published literature, museum collections, and personal contacts. We cross-referenced OBIS and GBIF data to avoid duplication of records. We excluded all records that were classified as fossils, were mapped on land, had location coordinates that either had no precision estimates, or if location precision was more than $100 \mathrm{~km}$. All species' names were verified in World Register of Marine Species (WoRMS), and their synonyms and misspellings were reconciled. We also re-examined razor clams in the collections of the Natural History Museum of Paris, Auckland Museum in New Zealand, the National Museum of Natural History (Smithsonian) in Washington, D.C., and the Natural History Museum of London. The specimens' identify was corrected if misidentified and geographic locations recorded. The museums were selected because of convenience of access (Auckland) and likelihood of holding large Solen collections. We found reliable coordinates for all 67 accepted Solen and Solena species that were listed in WoRMS. For the family level distribution modelling, we also included Solen gordonis which is described as taxon inquirendum (a questionable species that requires revision and may or may not prove to be a valid species) in WoRMS. We further found an extra nine potential species described as aff. and cf. In total, 77 Solenidae taxa were used in this study [17].

\section{Environmental data}

Developing a species distribution model needs environmental variables which are likely to influence the species' distribution [22]. Environmental variables were selected regarding their relevance to Solenidae distribution and their biological importance in affecting Solen species populations and diversity [23]. As razor clams are distributed in coastal waters, distance to land, depth, salinity, $\mathrm{pH}$, tidal height, and wave height could be important factors in limiting their distributions [14, 17, 24, 25]. While regionally depth and distance to land may be correlated, they are not globally $(\mathrm{r}=-0.46, \mathrm{p} \geq 0.05$, Additional file 1: Table S1) because of the variation in sizes of continental shelves and occurrence of mid-ocean islands. Sea surface temperature (SST), dissolved and saturated oxygen, and surface current may also affect the distribution, growth, reproduction, juvenile survival and mortality of Solen species [14, 17, 26-29]. Razor clams are filter feeders and consume phytoplankton as a food source. Thus, inorganic nutrients (such as silicate, nitrate, and phosphate), photosynthetically active radiation, diffuse attenuation coefficient (an indicator which shows how deeply visible light penetrates into the water column), chlorophyll- $a$ concentrations, and primary productivity could indirectly or directly affect the distribution of Solenidae $[14,25,30,31]$. Calcite was included because razor clams need calcium carbonate $\left(\mathrm{CaCO}_{3}\right)$ for shell growth [32].

Most environmental data layers were extracted from Global Marine Environment Datasets (GMED) [33] at a spatial resolution of 5 arcmin $\left(0.083^{\circ}\right.$ grid cell pixel size, ca. $9 \mathrm{~km}$ at equator) (Table 1). Ocean area $\left(\mathrm{km}^{2}\right)$ and coastline length including islands $(\mathrm{km})$ were extracted from Biogeoinformatics of Hexacorals (http://www. kgs.ku.edu/Hexacoral/) [34]. Layers were cropped to $70^{\circ} \mathrm{N}-70^{\circ} \mathrm{S}$ based on the maximum geographic distributions recorded for Solenidae species at latitudes $60^{\circ} \mathrm{N}$ and $50^{\circ} \mathrm{S}$. Merow et al. (2013) found that, with the exception of SST range, using multiple derivatives of SST did not improve the performance of their model compared to using only a single derivation of SST [35]. For this reason, we calculated correlation coefficients of all selected GMED variables in ArcGIS using multivariate analysis (Band Collection Statistics) (Table S1), and select only one derivation of each metric, that is the mean, minimum, or maximum of temperature and chlorophyll- $a$ concentration following Basher et al. (2014) [36]. Thus, 
Table 1 List of environmental variables used in this study (from Basher et al. 2014) which were cropped to an extension of $70^{\circ} \mathrm{N}-70^{\circ} \mathrm{S}$

\begin{tabular}{|c|c|c|c|c|c|c|c|}
\hline Layer & Unit & Type & Temporal range & Minimum & Maximum & Mean & Std. Dev. \\
\hline Land distance & $\mathrm{km} \times 100$ & - & - & 0.00 & 24.92 & 6.80 & 5.22 \\
\hline $\begin{array}{l}\text { Sea surface temperature (annual } \\
\text { mean) }\end{array}$ & ${ }^{\circ} \mathrm{C}$ & Monthly climatology & $2002-2009$ & -1.00 & 31.54 & 15.89 & 10.44 \\
\hline Sea surface temperature (range) & ${ }^{\circ} \mathrm{C}$ & Monthly climatology & 2002-2009 & 0.00 & 27.81 & 4.26 & 3.08 \\
\hline Depth & $\mathrm{m}$ & - & - & $-10,293.65$ & 0 & -3671.68 & 1602.58 \\
\hline Wave height & $\mathrm{m}$ & - & - & 0.00 & 7.00 & 0.29 & 1.02 \\
\hline $\begin{array}{l}\text { Photosynthetically active radiation } \\
\text { (annual mean) }\end{array}$ & Einstein $\mathrm{m}^{-2}$ day $^{-1}$ & Monthly climatology & 1997-2009 & 0.00 & 64.82 & 35.22 & 8.55 \\
\hline $\begin{array}{l}\text { Chlorophyll-a concentration } \\
\text { (annual mean) }\end{array}$ & $\mathrm{mg} \mathrm{m}^{-3}$ & Monthly climatology & $2002-2009$ & 0.02 & 0.90 & 0.05 & 0.04 \\
\hline $\begin{array}{l}\text { Diffuse attenuation coefficient* } \\
\text { (at } 490 \mathrm{~nm} \text { ) }\end{array}$ & $m^{-1}$ & Monthly climatology & $2002-2009$ & 0.02 & 0.90 & 0.05 & 0.04 \\
\hline Primary Productivity & $\mathrm{mg} C \mathrm{~m}^{-2}$ day $^{-1}$ cell $^{-1}$ & Annual climatology & - & 0.00 & 4875.00 & 385.08 & 285.55 \\
\hline $\begin{array}{l}\text { Tide average (average of maxi- } \\
\text { mum tidal height) }\end{array}$ & $\mathrm{m}$ & Annual climatology & - & 0.00 & 6.38 & 0.51 & 0.44 \\
\hline Surface current & $\mathrm{ms}^{-1}$ & Monthly climatology & 2009-2010 & -0.93 & 1.00 & 0.00 & 0.08 \\
\hline Salinity & PSS & In situ measure: 2009 & $1961-2009$ & 0.00 & 41.00 & 33.96 & 2.09 \\
\hline $\mathrm{pH}$ & - & In situ measure: 2009 & 1910-2007 & 6.73 & 8.62 & 8.19 & 0.06 \\
\hline Dissolved oxygen & $\mathrm{ml} \mathrm{I}^{-1}$ & In situ measure: 2009 & $1898-2009$ & 2.00 & 9.86 & 5.29 & 1.27 \\
\hline Saturated oxygen & $\mathrm{ml} \mathrm{I}$ & In situ measure: 2009 & $1874-2000$ & 76.05 & 113.11 & 100.10 & 3.23 \\
\hline Calcite concentration & $\mathrm{mol} \mathrm{m}^{-3}$ & Seasonal climatology & $2002-2009$ & 0.00 & 9.00 & 2.87 & 3.18 \\
\hline Silicate & $\mu \mathrm{mol} \mathrm{I}^{-1}$ & In situ measure: 2009 & 1930-1986 & 0.00 & 69.00 & 9.85 & 13.86 \\
\hline Nitrate & $\mu \mathrm{mol} \mathrm{I}^{-1}$ & In situ measure: 2009 & 1922-1986 & 0.00 & 45.96 & 5.52 & 6.13 \\
\hline Phosphate & $\mu \mathrm{mol} \mathrm{I}^{-1}$ & In situ measure: 2009 & $1874-2000$ & 0.00 & 2.00 & 0.26 & 0.44 \\
\hline Sea surface temperature at 2100 & ${ }^{\circ} \mathrm{C}$ & Monthly climatology & $2087-2096$ & 0.00 & 35.05 & 18.04 & 10.91 \\
\hline Salinity at 2100 & PSS & Monthly climatology & $2087-2096$ & 0.00 & 40.05 & 34.37 & 1.99 \\
\hline Primary productivity at 2100 & $\mathrm{mg} C \mathrm{~m}^{-2}$ day $^{-1} \mathrm{cell}^{-1}$ & Annual climatology & 2090-2099 & 0.00 & 5004.00 & 354.76 & 277.07 \\
\hline
\end{tabular}

Future environmental variables are in italics. Note that there were 19 variables for the Present, and 5 (including present land distance and depth as constant variables, and three future environmental variables in italics) for the Future model. Annual means were used and for sea surface temperature the annual range was also used as it was significantly different from the sea surface temperature annual mean. ${ }^{*}$ An indicator of water clarity which expresses how deeply visible light in the blue to the green region of the spectrum penetrates into the water column. Distance to land was the distance to the nearest land using the Euclidean distance formula in ArcGIS

we only used annual mean SST and mean chlorophyll-a concentration.

In total, 19 environmental data layers were used to create the present day distribution models at both a family level and a species level (Table 1). However, for the future climate change scenarios there were only three environmental variables available, namely salinity, primary productivity, and SST mean. We assumed distance to land and depth would be similar until 2100, and thus predicted future geographic distributions by comparing the five variables including distance to land, depth, salinity, primary productivity, and SST mean for the present (reduced present day model) and future scenarios (Table 1). The differences between the mean values for the present and future environmental variables were $2{ }^{\circ} \mathrm{C}$ greater for sea surface temperature, 0.4 PSS less for salinity, and $30 \mathrm{mg} \mathrm{C} \mathrm{m}^{-2}$ day $^{-1}$ cell $^{-1}$ less for primary productivity (but $129 \mathrm{mg} \mathrm{C} \mathrm{m}^{-2}$ day $^{-1}$ cell $^{-1}$ greater maximum) (Table 1).

\section{Modelling of species distributions}

MaxEnt was selected in this study due to its success in developing species distribution models for marine species [37-40]. It has been widely used in conservation planning, ecology, evolution, epidemiology, invasive-species management and other fields [3, 6, 37]. MaxEnt minimizes the relative entropy, or dispersion, between two probability densities, one estimated from presence data, and one from the landscape in the context of covariate space. MaxEnt is optimized for predicting the realised or actual (rather than the fundamental) species distributions. Predictions of presence will thus still be dependent on the sample locations of the available data $[7,37]$. Thus, any deficiency in sampling coverage might still bias the results $[7,41,42]$.

MaxEnt version 3.3.3e was used to predict present and future (at year 2100) suitable environments for Solenidae on a global scale at both the family and species level. At the family level, a total of 526 distribution records of 
77 Solenidae species were used for training the model [17] (see also Additional file 1: Table S2). Modelling at the family level allowed coverage of all species globally. Because of the greater number of distribution records the family level mapping would encompass each species level prediction. This if a species level model predicted a distribution outside the family level it would suggest poor model accuracy due to insufficient primary data.

MaxEnt was used to predict the suitable present and future environments for 14 Solen species which had more than 10 presence records separately (Table S2). We used one observation point per $0.083^{\circ}$ pixel, to eliminate any duplicate points and reduce clumping. Models were created with 10 bootstrap replicates using default parameters for a random seed: randomly select $75 \%$ of the species presence records for training and $25 \%$ for testing the model in each replication stage $[37,43]$. Then the average predictions across the all replicates were used for further analysis. The regularization multiplier was set to 1 , and the maximum number of background points was increased to 100,000 instead of the default because of our large-scale mapping objective. There were 900 maximum iterations, and a convergence threshold of 0.00001 for the present day modelling [7, 23, 44]. We kept the default regularization values following Dudik et al. (2006) [45] as they result in better performance of evaluation data for presence only datasets. For the future projections, 10 cross-validated replicate models were generated. Default parameters including hinge features, random test percentage of zero [37, 43], and the other settings were the same as in the present day modelling.

To test the performance of MaxEnt models we used the Receiver Operating Characteristic (ROC) analysis. ROC analysis characterises the performance of a model at all possible thresholds using the Area Under the Curve (AUC) $[6,23,44]$. The highest numbers of AUC show more sensitive and specific model sets, ranging from 0.5 (random accuracy) to 1.0 (perfect discrimination) [7, 44]. We used the cumulative threshold value from the MaxEnt output which is a balance among training omission, predicted area, and threshold value. Values observed below the thresholds were considered to be unsuitable for the species. To determine the most important factors in training the distribution models and creating the final distribution models, we used the model outputs of the jacknife test as well as contribution rate (represents the importance of a given variable in model training), and permutation importance [46]. Permutation importance depends only on the final Maxent model (not for the replicates). The contribution for each factor is determined by randomly permuting the values of that factor among the points used for training the model and measuring the variation of AUC (training) value. A large decrease indicates that the model depends heavily on that factor. Final values are normalized to a percentage for easier interpretation [46].

A map of environment suitability for Solenidae was generated to reflect the predicted probability of species occurrence using ArcGIS v10 [36, 43]. The model often predicted suitable environment in areas that were not contiguous with species' present distributions. For example, an Australian species in Japan, an Atlantic species on both coasts of north America, and Indian Ocean species in the Mediterranean. Such distributions are only likely if species are introduced by human activities. No marine species' are known to have larvae that disperse more than $1000 \mathrm{~km}[47,48]$. Thus, when determining both present and future predicted distribution ranges, only continuous distribution ranges within a maximum of $30^{\circ}$ latitude (equivalent to $3300 \mathrm{~km}$ ) and $30^{\circ}$ longitude, and with more than a $75 \%$ prediction rate beyond the reported distribution were considered.

\section{Results}

\section{Present model with 19 variables at family level}

Distance to land and depth had the highest contribution rates and importance in creating the present distribution models at the family level (about 75\%) (Additional file 1: Fig S1). After distance to land and depth, mean SST had the highest contribution rate $(9.3 \%)$ in training the models, and wave height had the most importance rate in creating the final distribution models (Fig S1). The probability of Solenidae family occurrence in the present distribution models was close to 1 (the highest probability rate) where: distance to land was between 0 and $100 \mathrm{~km}$; depth was $0-150 \mathrm{~m}$; mean SST between 12 and $28{ }^{\circ} \mathrm{C}$; wave height $5-7 \mathrm{~m}$; and mean chlorophyll- $a$ concentration $0.7 \mathrm{mg} \mathrm{m}^{-3}$ (Additional file 1: Fig S2).

\section{Present model with 19 variables for 14 species}

Species occurrences were strongly associated with wave height and distance to land which had the highest contribution rates in training the present distribution models of 10 species (about 70\%) (Table 2). In the remaining four species, SST mean, SST range, dissolved oxygen, and depth had the highest contribution rates in training the present distribution models. Depth, distance to land, and calcite had the highest permutation importance in creating the final present distribution models (Table 2). The probability of Solen species occurrence in the present distribution models was close to 1 where: distance to land was approximately less than $200 \mathrm{~km}$; depth less than $150 \mathrm{~m}$; mean SST between 12 and $32{ }^{\circ} \mathrm{C}$; primary productivity between 500 and $2500 \mathrm{mg} \mathrm{C} \mathrm{m}^{-2}$ day $^{-1}$ cell $^{-1}$, and salinity between 23 and 41 PSS (Table 3). In a total of 14 species, four cold temperate species including Solen 
Table 2 The output of highest contribution and importance values of environmental variables in creating the present MaxEnt distribution models for 14 species using 19 variables

\begin{tabular}{|c|c|c|c|c|c|}
\hline \multirow[t]{2}{*}{ Solen species } & \multirow[t]{2}{*}{ Training records } & \multicolumn{2}{|l|}{ Contribution } & \multicolumn{2}{|c|}{ Permutation importance } \\
\hline & & Highest & Rate (\%) & Highest & Rate (\%) \\
\hline aureomaculatus & 15 & Wave height & 22.8 & Depth & 32.2 \\
\hline canaliculatus & 12 & SST mean & 19.0 & Land distance & 39.2 \\
\hline fonesii & 50 & Wave height & 22.2 & Calcite & 28.7 \\
\hline grandis & 24 & SST range & 53.2 & Land distance & 56.7 \\
\hline kajiyamai & 12 & Dissolved oxygen & 29.6 & Depth & 56.1 \\
\hline marginatus & 126 & Land distance & 42.8 & Calcite & 34.5 \\
\hline roseomaculatus & 35 & Wave height & 33.6 & Land distance & 84.7 \\
\hline sicarius & 30 & Land distance & 60.9 & Depth & 67.4 \\
\hline sloanii & 15 & Land distance & 60.9 & Depth & 67.4 \\
\hline strictus & 17 & Land distance & 28.0 & Depth & 46.4 \\
\hline thuelchus & 12 & Wave height & 25.1 & Land distance & 52.0 \\
\hline vagina & 10 & Land distance & 28.4 & Calcite & 21.6 \\
\hline vaginoides & 85 & Depth & 24.4 & Calcite & 38.5 \\
\hline viridis & 33 & Wave height & 29.3 & Land distance & 33.2 \\
\hline
\end{tabular}

Values are normalized to give percentages. The average AUC of training data was from 0.97 to 1 from the ten model runs, with little variation between runs indicating a good model fit

grandis, S. marginatus, S. thuelchus, and S. viridis preferred the lowest temperature ranges from 12 to $16^{\circ} \mathrm{C}$, two warm temperate species including Solen sicarius and $S$. strictus had a temperature preferences from 16 to $19^{\circ} \mathrm{C}$, and the rest were tropical species with high temperature preferences from 25 to $32^{\circ} \mathrm{C}$. Four species of 14 species including Solen canaliculatus, S. roseomaculatus, S. sloani, and S. vagina favoured high salinities from 40 to 41 PSS, S. sicarius preferred the low salinity from 23 to 25 PSS, and the rest of species mostly predicted in salinities from 29 to 39 PSS (Table 3).

\section{Reduced present models with 5 variables for 14 species}

Depth and distance to land had the highest contribution rates in training and creating the reduced present distribution models for almost all Solen species, except for Solen marginatus where mean SST had the highest importance permutation rate in creating the final distribution models (Table 4).

\section{Future models with 5 variables at family level}

Distance to land and depth had the highest contribution rates and importance in creating the future distribution models at the family level (about 85\%) (Fig S1). Mean SST had the highest contribution rate $(11.7 \%)$ in training the future projections after distance to land and depth. However, primary productivity was the third important factor in creating the future distribution models after distance to land and depth (Fig S1). The probability of Solenidae family occurrence in the future distribution models was close to 1 where: distance to land was between 0 and $100 \mathrm{~km}$; depth $0-150 \mathrm{~m}$; mean SST $12-28{ }^{\circ} \mathrm{C}$; primary productivity between 500 and $2000 \mathrm{mg} \mathrm{C} \mathrm{m}^{-2}$ day $^{-1}$ cell $^{-1}$; and salinity between 30 and 38 PSS (Additional file 1: Fig S3).

\section{Future models with 5 variables for 14 species}

In all 14 species excluding $S$. aureomaculatus, distance to land had the highest contribution rate in training the future distribution models (Table 4). However, mean SST was the most important factor in creating the final future distribution models in half of the 14 Solen species (50\%). After mean SST, depth in five species (36\%), and distance to land in two species (14\%) were the most important factors in creating the final future distribution models. The probability of Solen species future distributions was close to 1 where distance to land was less than $200 \mathrm{~km}$; depth less than $150 \mathrm{~m}$; mean SST $11-29^{\circ} \mathrm{C}$; primary productivity between 500 and $2300 \mathrm{mg} \mathrm{C} \mathrm{m}^{-2}$ day $^{-1}$ cell $^{-1}$; and salinity between 32 and 42 PSS (Table 3).

The maximum averages of predicted suitable primary productivity for Solen canaliculatus, S. kajiyamai, $S$. marginatus, and S. roseomaculatus were lower in the future distribution models compared to the present distribution models (Table 3). Predicted suitable salinities in the future distribution models were higher compared to the present distribution models in all species, except for $S$. canaliculatus. The maximum predicted suitable SST mean in half of the species was lower in the future distribution models compared to the present distribution 
Table 3 The variables that had the highest predicted probability of Solen species occurrence for the present and future distribution models

\begin{tabular}{|c|c|c|c|c|c|c|c|c|}
\hline \multirow[t]{2}{*}{ Solen Species } & \multirow[t]{2}{*}{ Depth (m) } & \multicolumn{3}{|l|}{ Present } & \multirow[t]{2}{*}{ Depth (m) } & \multicolumn{3}{|l|}{ Future } \\
\hline & & $\begin{array}{l}\text { Primary pro- } \\
\text { ductivity (mg } \\
\mathrm{C} \mathrm{m}^{-2} \text { day }^{-1} \\
\text { cell }^{-1} \text { ) }\end{array}$ & Salinity (PSS) & $\begin{array}{l}\text { Mean sea sur- } \\
\text { face tempera- } \\
\text { ture }\left({ }^{\circ} \mathrm{C}\right)\end{array}$ & & $\begin{array}{l}\text { Primary pro- } \\
\text { ductivity (mg } \\
\mathrm{C}^{-2} \text { day }^{-1} \\
\text { cell }^{-1} \text { ) }\end{array}$ & Salinity (PSS) & $\begin{array}{l}\text { Mean sea } \\
\text { surface } \\
\text { temperature } \\
\left({ }^{\circ} \mathrm{C}\right)\end{array}$ \\
\hline aureomaculatus & $0-150$ & $500-750$ & $35-36$ & $26-28$ & $0-150$ & 500-1000 & $40-42$ & $25-28$ \\
\hline canaliculatus & $0-150$ & $2000-2500$ & $40-41$ & $29-31$ & $0-150$ & $750-1000$ & $32-34$ & $25-28$ \\
\hline fonesii & $0-150$ & $800-1100$ & $34-35$ & $27-30$ & $0-150$ & $800-1100$ & $35-36$ & $25-29$ \\
\hline grandis & $0-150$ & $1900-2000$ & $30-32$ & $13-14$ & $0-150$ & $1800-2000$ & $30-33$ & $13-14$ \\
\hline kajiyamai & $0-150$ & $1800-2000$ & $39-40$ & $30-31$ & $0-150$ & $1500-1700$ & $40-41$ & $22-25$ \\
\hline marginatus & $0-100$ & 1500-1900 & $39-40$ & $12-13$ & $0-100$ & $1400-1600$ & $40-41$ & $11-13$ \\
\hline roseomaculatus & $0-150$ & $1400-1600$ & $40-41$ & $31-32$ & $0-150$ & $1000-1200$ & $41-42$ & $23-26$ \\
\hline sicarius & $0-150$ & $2200-2300$ & $23-25$ & $16-17$ & $0-150$ & $2200-2300$ & $32-33$ & $15-17$ \\
\hline sloanii & $0-100$ & $750-850$ & $40-41$ & $25-26$ & $0-100$ & $750-1000$ & $41-42$ & $23-25$ \\
\hline strictus & $0-100$ & $1800-2000$ & $29-31$ & $17-19$ & $0-100$ & 1500-1700 & $32-33$ & $18-19$ \\
\hline thuelchus & $0-100$ & $2200-2100$ & $39-41$ & $13-16$ & $0-100$ & $2200-2000$ & $40-41$ & $15-16$ \\
\hline vagina & $0-150$ & $1600-1900$ & $40-41$ & $25-28$ & $0-150$ & $1600-2100$ & $41-42$ & $26-28$ \\
\hline vaginoides & $0-100$ & $800-1100$ & $38-40$ & $26-28$ & $0-100$ & $800-1100$ & $39-41$ & $26-27$ \\
\hline viridis & $0-100$ & $2000-2100$ & $38-39$ & $12-14$ & $0-100$ & $2000-2200$ & $38-40$ & $12-13$ \\
\hline
\end{tabular}

Distance to land was approximately less than $200 \mathrm{~km}$ for all species in both present and future distribution models

models, and it did not change for the remainder. Temperate species such as Solen grandis, S. marginatus, S. strictus, S. sicarius, S. thuelchus, and S. viridis had the lowest predicted suitable SST ranges from 12 to $19{ }^{\circ} \mathrm{C}$ in both present and future distribution models (Table 3).

\section{Present distributions}

More than $50 \%$ of species showed similar present predicted distribution ranges compared to their actual distribution ranges (Fig. 1). MaxEnt distribution model outputs at the family level indicated that the most suitable environments for Solenidae at present are in the shallow waters of the northern east Pacific (California, USA), tropical west Atlantic (north Carolina, USA), European Atlantic, Gulf of Thailand, and eastern (Brisbane and Melbourne) and western coast of Australia (Additional file 1: Fig S4).

\section{Future distributions}

Solen sloanii and S. roseomaculatus were distributed in both hemispheres and had the widest latitudinal distribution ranges of all the species (Figs. 1,2). They were predicted to shift northward in the northern, and southward in the southern hemisphere under the future climate change scenarios (Table S2, Figs. 1, 2, 3). Solen vagina seems to be an endemic species to the Gulf of Thailand and was predicted to shift southward to Malaysia, Singapore, and Indonesia. Solen strictus and S. grandis showed similar future distribution ranges compared to their current distributions. Solen canaliculatus was predicted to shift northward from its present distributions and disappear from Taiwan in the future distribution model. High latitude species such as Solen marginatus, S. sicarius, and $S$. viridis were predicted to shift northward in the northern, and S. thuelchus southward in the southern hemisphere. However, the extent of their predicted distribution ranges in the present and future distribution models were similar. All Australian species including Solen fonesii, S. kajiyamai, S. aureomaculatus, and S. vaginoides were predicted to shift southward along the eastern and southern Australia coasts in the future models such that the species' would split into east and west coast populations. All Australian species disappeared from the northern part of Australia under future climate change (Table S2, Figs. 1, 2).

At the family level, more geographic areas were predicted to be suitable for razor clams in the future compared to the present distribution models (Additional file 1: Fig S5). This is supported by the results of individual species models. Considering predicted present and future distribution models at the species level, half of the 14 species had a wider distribution range in the future compared to predicted present distribution models (Fig. 3). In contrast, three species (21\%), namely Solen vaginoides, $S$. strictus, and $S$. viridis were predicted to have narrower latitudinal distribution ranges in the 


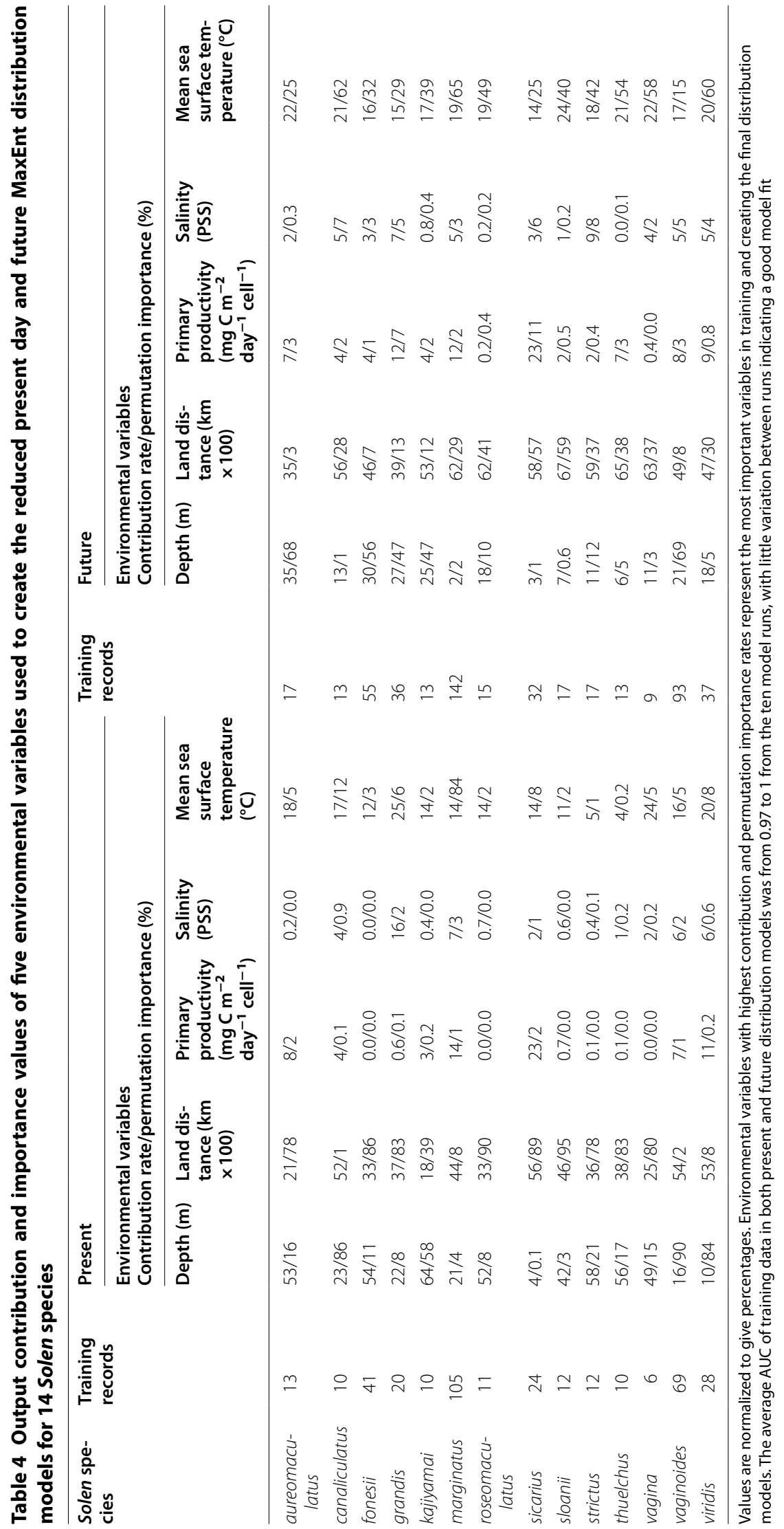




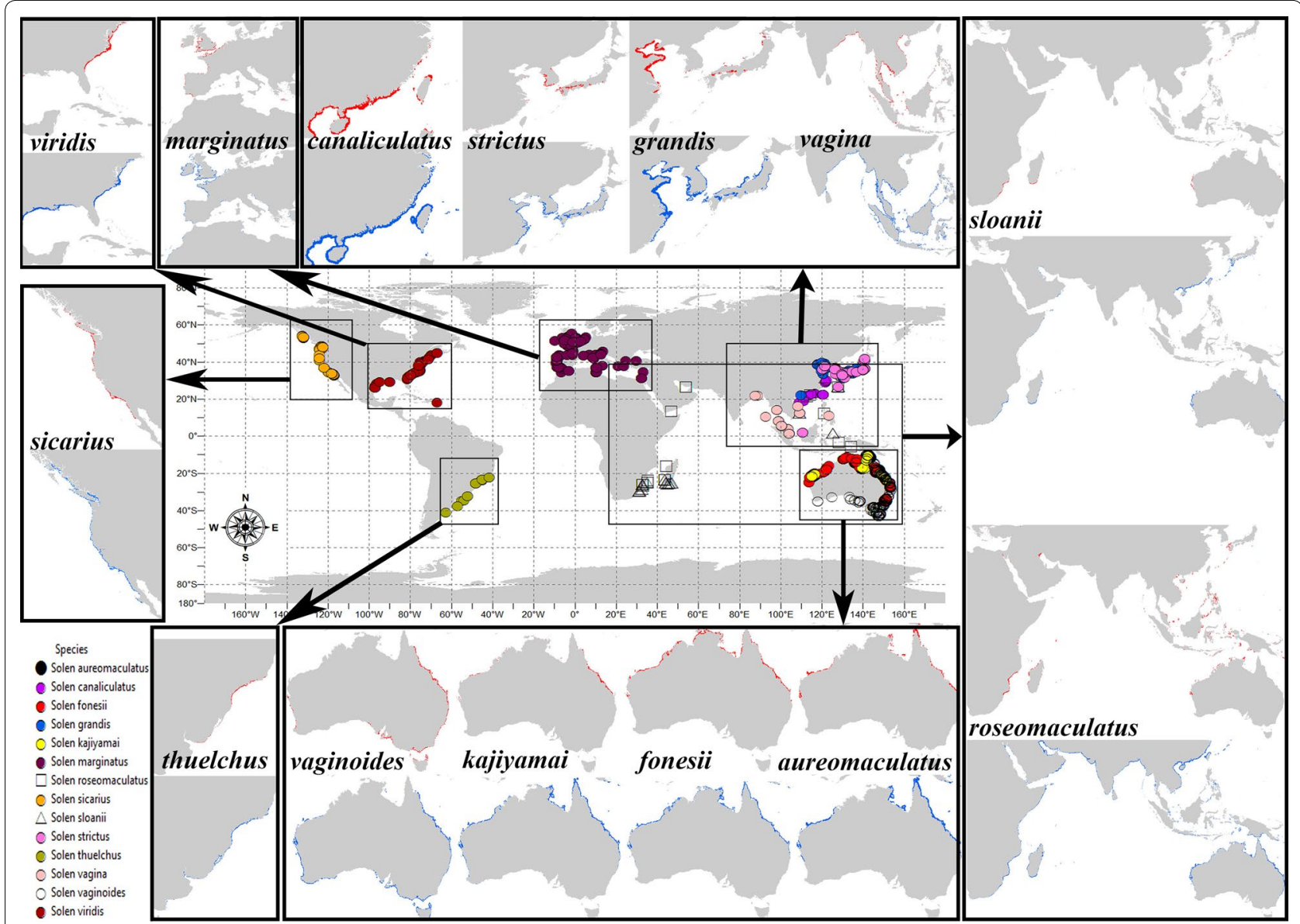

Fig. 1 The reported species distribution map of 14 Solen species is presented in the central panel. The symbols show the actual distributions of each species. Predicted present (top models in red) and future (2100) (bottom models in blue) distribution models of environment suitability for 14 Solen species with a probability of occurrence $>0.5$

future. Four species (29\%) had similar present and future distribution ranges indicating that their distribution would not change due to future climate change. A species range may change but the mean latitude of its ranges may or may not change. The mean latitudes of the northern hemisphere species were predicted to change showing a negligible change in the future (Fig. 4). However, the mean latitude of southern species would shift southward.

\section{Discussion}

\section{Present distributions}

The majority of the predicted suitable environments were in the shallow waters of the temperate and tropical north America, Indo-West Pacific, and the European Atlantic Ocean where Solenidae have been reported. Some of these areas may not be inhabited by Solen at present due to dispersal constraints. For example, there were no distribution records of Solenidae in New Zealand; although the model predicted this area had a suitable environment now and in the future. This would suggest that this family had not occurred on Gondwanaland or evolved prior to the separation of New Zealand from Australia (around 80 million years ago). During glaciations, SST in northern New Zealand were above $10{ }^{\circ} \mathrm{C}[49]$ which is within the temperature tolerance of Solenidae. Evidently, the duration and/or behaviour of Solenidae planktonic larvae might have been insufficient for species to colonise New Zealand from Australia.

The environment suitability model developed in this study indicated that Solenidae species' distributions were highly correlated with distance to land, depth, SST, and wave height. Distance to land and depth contributed to over $70 \%$ of the variation in the models. Mean SST had the next most contribution rate (about 9\%) to the global models after distance to land and depth. SST is a major factor in the reproduction, larval development, recruitment, and mortality of Solenidae [14, 31].

The models predicted Solenidae to occur in coastal areas $(\leq 200 \mathrm{~km}$ from the land) with depths of less than 


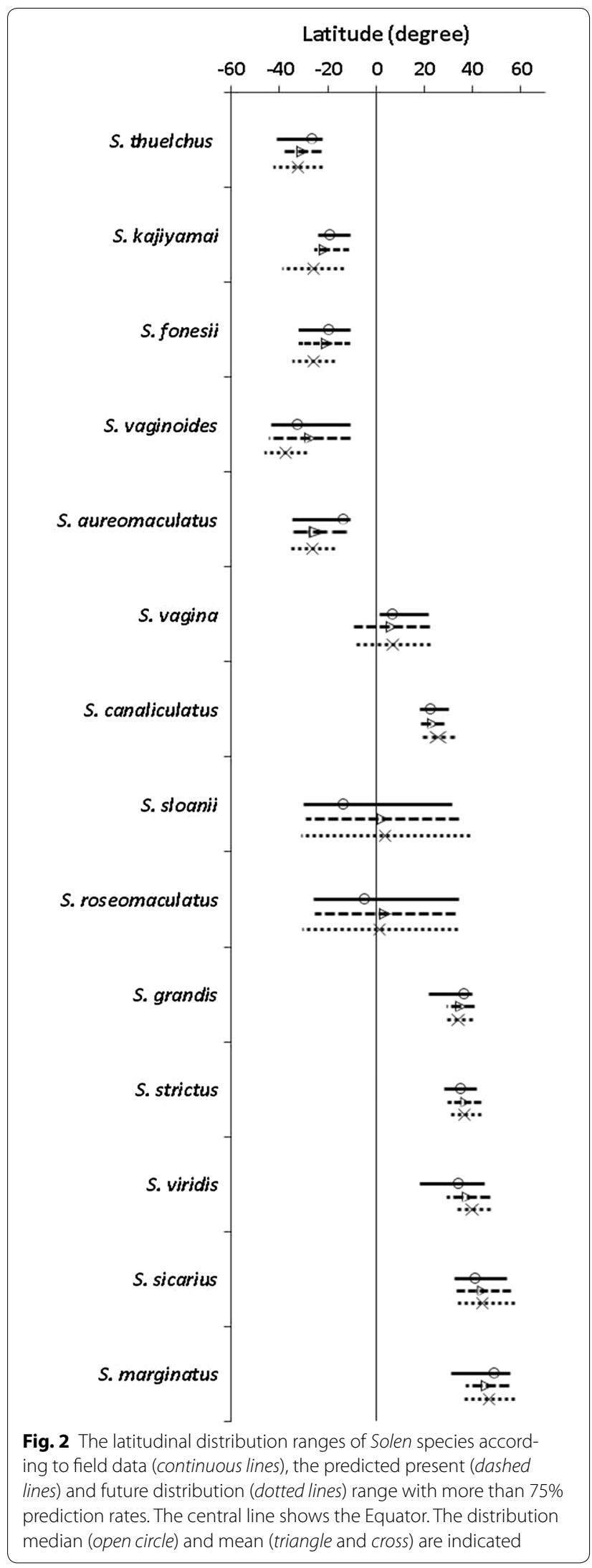

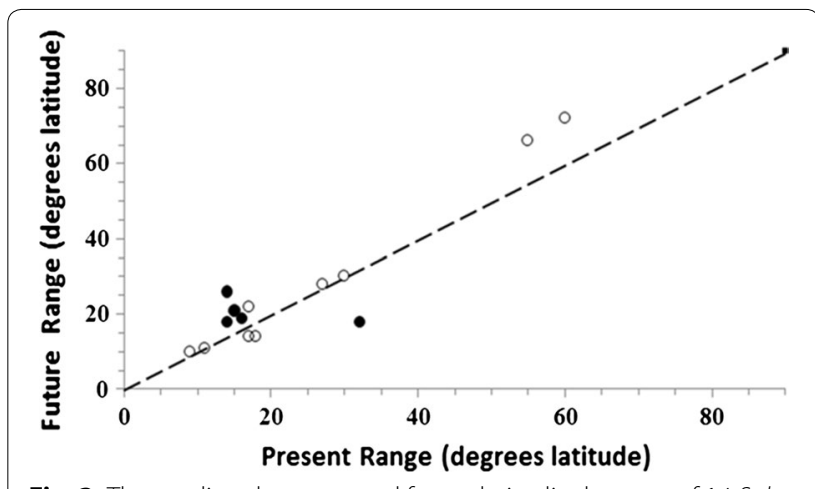

Fig. 3 The predicted present and future latitudinal ranges of 14 Solen species. Symbols above the line indicate a wider latitudinal range, and symbols below the line indicate a predicted decrease in the species latitudinal range. Black circles: southern latitudes (5 species); open circles: northern latitudes (9 species)

$150 \mathrm{~m}$, wave height of $5-7 \mathrm{~m}$, mean SST of $12-28^{\circ} \mathrm{C}$, and primary productivity of $400-700 \mathrm{mg} \mathrm{C} \mathrm{m}^{-2}$ day $^{-1}$ cell $^{-1}$ ). The suitable environments for Solenidae species were similar to the temperate razor clam Ensis directus (Pharidae) [50]. They also found high probabilities of occurrence for $E$. directus at depths between 0 and $67 \mathrm{~m}$, minimum annual SSTs between 3 and $18{ }^{\circ} \mathrm{C}$ and maximum annual SSTs between 20 and $26.5^{\circ} \mathrm{C}$ [50].

Wave height had the highest contribution rate in training the present distribution models of most high latitude species including Solen aureomaculatus, S. fonesii, $S$. thuelchus, and $S$. viridis. The greater occurrence of Solenidae in areas with 5-7 $\mathrm{m}$ wave height, which is at the upper end of the range of potential wave height, may be an indicator of the occurrence of sandier sediments. Nickerson (1975) reported that densities of razor clams were highest on sandy beaches with least silt, and that silt-laden sediments might be responsible for suffocation of razor clams in early life stages [51].

\section{Future distributions}

Mean SST was the most important environmental variable in half of the species in creating the final future distribution models. The future species distribution models showed that northern and southern hemisphere species would shift northward and southward respectively under future climate warming. Half of the species were predicted to expand their distribution ranges $21 \%$ of species to shrink, and $29 \%$ of species did not change their distribution under future climate change. The potential poleward range shifts due to global warming have been also reported for sandy-beach invertebrates [5] and tropical molluscs [2]. Indo-West Pacific areas (especially China Sea, Sea of Japan, Bay of Bengal, Gulf of Thailand, Andaman Sea, Philippines, Indonesia, and Papua New Guinea) 


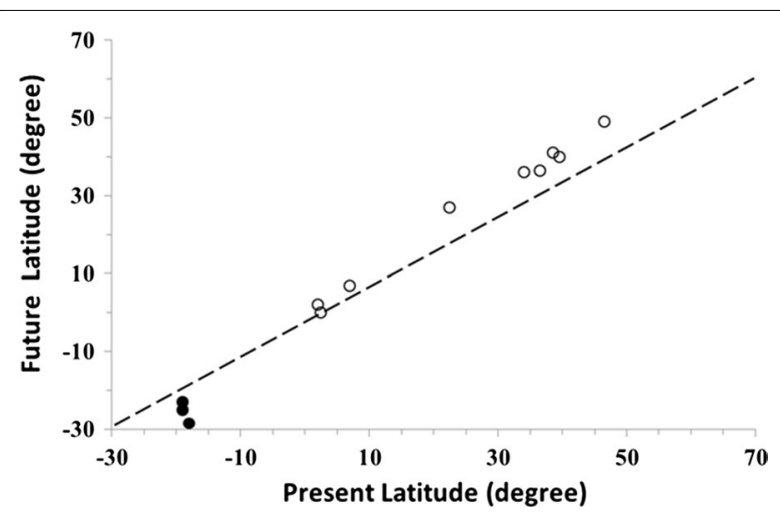

Fig. 4 The predicted present and future mean latitude of distribution in 14 Solen species. Symbols above the dashed line indicate a northward, and below a southward, shift in mean latitude under the predicted future climate change. Black circles: southern latitudes ( 5 species); open circles: northern latitudes ( 9 species). All northern latitude species shift northward and all southern latitude species shift southward

would be occupied by more Solen species due to the warming average temperatures, as predicted for other tropical molluscs [2]. Distributions of tropical S. canaliculatus, S. vagina, S. strictus, and S. grandis could also expand northward and southward along the coastal areas of the China Sea, Sea of Japan, Bay of Bengal, and Gulf of Thailand under future climate change. However, physical geographical barriers would limit future distribution changes into these areas $[11,18]$.

Almost all Australian species were predicted to shift their distribution southwards and disappear from its northern territory. The sea surface temperature in northern Australia is predicted to become $2-3{ }^{\circ} \mathrm{C}$ warmer $\left(33{ }^{\circ} \mathrm{C}\right)$ in the future [52] which would be out of these species temperature tolerance [17]. In contrast, the predicted future distribution models of some high latitude species, such as $S$. marginatus and S. sicarius, would not expand outside their current distribution ranges.

The present and future distribution models in Solen roseomaculatus and $S$. sloanii showed exceptionally wide disjunct distributions. These merit confirmation because they may reflect misidentifications as a consequence of their subtle differences in shell morphology and lack of molecular taxonomy studies. Thus they could be more than one species $[17,53]$.

\section{Conclusions}

Saeedi et al. (in press) found that the latitudinal distribution of Solenidae was bimodal, with most species at the edges of the tropics. They suggested this may be typical for marine species in general, because such bimodality has also been found for taxa as varied as planktonic foraminifera and marine mammals [20]. The results of the present study show that this bimodality is likely to increase due to climate warming, and will result in increased species richness at regional scales because most species will increase their geographic range. Thus climate warming can be considered as an unintended global experiment that confirms the role of temperature in defining the latitudinal distribution of marine species.

\section{Additional file}

Additional file 1. Input environmental variables and geographic distribution data, and output results of the present and future distribution modelling. This file includes the additional data on correlations between the environmental variables, input geographic distribution points of Solenidae species used in the present and future modelling, and the models' output which could not be fitted inside the paper due the page limits.

\section{Abbreviations}

MaxEnt: maximum entropy; SST: sea surface temperature; GBIF: Global Biodiversity Information Facility; OBIS: Ocean Biogeographic Information System; WoRMS: World Register of Marine Species; GMED: Global Marine Environment Datasets; PSS: practical salinity scale; ROC: receiver operating characteristic; AUC: area under the ROC curve.

\section{Authors' contributions}

HS: study design, data collection, statistical analysis, species distribution modelling, writing the paper. ZB: environmental data interpretation, species distribution modelling, review of the paper. MJC: study design, statistical analysis, writing of the paper. All authors read and approved the final manuscript.

\section{Acknowledgements}

HS was supported by the New Zealand International Doctoral Scholarship (NZIDRS) and University of Auckland Doctoral Scholarship. We would like to thanks the referees for their helpful comments.

\section{Competing interests}

The authors declare that they have no competing interests.

\section{Availability of data and materials}

The dataset supporting the conclusions of this article is included within the article (and its Additional file 1).

\section{Funding}

This research was funded by the New Zealand International Doctoral Scholarship (NZIDRS) and University of Auckland Doctoral Scholarship. The funding bodies had no roles in the design of the study and collection, analysis, interpretation of data, and in writing the manuscript.

Received: 20 May 2016 Accepted: 4 November 2016

Published online: 20 December 2016

\section{References}

1. Cheung WWL, Lam VWY, Sarmiento JL, Kearney K, Watson R, Pauly D. Projecting global marine biodiversity impacts under climate change scenarios. Fish Fish. 2009;10(3):235-51.

2. Saupe EE, Hendricks JR, Peterson AT, Lieberman BS. Climate change and marine molluscs of the western North Atlantic: future prospects and perils. J Biogeogr. 2014;41(7):1352-66.

3. Rombouts I, Beaugrand G, Dauvin JC. Potential changes in benthic macrofaunal distributions from the English Channel simulated under climate change scenarios. Estuar Coast Shelf Sci. 2012;99:153-61. 
4. Sarà G, Milanese M, Prusina I, Sarà A, Angel DL, Glamuzina B, Nitzan T, Freeman S, Rinaldi A, Palmeri V, Montalto V, Lo Martire M, Gianguzza P, Arizza V, Lo Brutto S, De Pirro M, Helmuth B, Murray J, De Cantis S, Williams $G A$. The impact of climate change on mediterranean intertidal communities: losses in coastal ecosystem integrity and services. Reg Environ Change. 2014;14(Suppl 1):5-17.

5. Schoeman DS, Schlacher TA, Defeo O. Climate-change impacts on sandy-beach biota: crossing a line in the sand. Glob Change Biol. 2014;20(8):2383-92.

6. Phillips SJ, Dud M, Schapire RE. A maximum entropy approach to species distribution modeling. Proceedings of the twenty-first international conference on Machine learning; Banff, Alberta, Canada. 1015412: ACM; 2004. p. 83.

7. Phillips SJ, Anderson RP, Schapire RE. Maximum entropy modeling of species geographic distributions. Ecol Model. 2006;190(3-4):231-59.

8. Elith J, Leathwick JR. Species distribution models: ecological explanation and prediction across space and time. Annu Rev Ecol Evol Syst. 2009:40(1):677-97.

9. Ashcroft MB, French KO, Chisholm LA. An evaluation of environmental factors affecting species distributions. Ecol Model. 2011;222(3):524-31.

10. Davies AJ, Guinotte JM. Global habitat suitability for framework-forming cold-water corals. PLoS ONE. 2011:6(4):e18483.

11. Cosel Rv, editor. An introduction to the razor shells (Bivalvia: Solenacea). Hong Kong: Hong Kong University Press; 1990

12. Saeedi H, Raad SP, Ardalan AA, Kamrani E, Kiabi BH. Growth and reproduction of Solen dactylus (Bivalvia: Solenidae) on northern coast of the Persian Gulf (Iran). J Mar Biol Assoc UK. 2009;89(8):1635-42.

13. Saeedi $\mathrm{H}$, Costello MJ. Cosel Rv. First report of anterior pallial tentacles in Solen dactylus (Bivalvia: Solenidae) from the Northern Persian Gulf, Iran. PLOS ONE. 2013;8(5):e63487.

14. Guerra A, Lodeiros C, Gaspar MB, da Costa F. Razor clams: biology, aquaculture and fisheries. Xunta de Galicia, Consellería do Mar, Santiago de Compostela. Spain 2011.

15. Lassuy DR, Newell RIE, Fritzsche RA, Hassler TJ, Simons D, Group USAEWESCE, et al. Species profiles: life histories and environmental requirements of coastal fishes and invertebrates (Pacific Northwest): Pacific razor clam: Defense Technical Information Center; 1989.

16. Saeedi $\mathrm{H}$, Ardalan AA, Kiabi HB, Zibaseresht R. Metal concentrations in razor clam Solen dactylus (Von Cosel, 1989) (Bivalvia: Solenidae), sediments and water in Golshahr coast of Bandar Abbas, Persian Gulf. Iran J Fish Sci. 2012;11(1):165-83.

17. Saeedi $\mathrm{H}$, Costello MJ, Dennis T. Bimodal latitudinal species richness and high endemicity in razor clams (Bivalvia: Solenidae). J Biogeogr. (to appear).

18. Cosel Rv. Seven new species of Solen (Bivalvia: Solenidae) from the tropical Western Pacific, with remarks on other species. In: 301-341; col. pls. 31-38. In: Falkner MG, K. \& Speight, C.D., editor.: Collectanea Malacologica - Festschrift für Gerhard Falkner: $10+547$ pp +48 col. Pls. Conchbooks, Hackenheim/Frierich-Held-Gesellschaft, München; 2002.

19. Saeedi $H$, Costello MJ. Aspects of global distribution of six marine bivalve mollusc families. In: da Costa F, editor. Clam fisheries and aquaculture. New York: Nova Science Publishers Inc.; 2013. p. 27-44.

20. Chaudhary C, Saeedi H, Costello MJ. Bimodality of latitudinal gradients in marine species richness. Trends Ecol Evol. 2016:31(9):670-6.

21. Costello MJ, Tsai P, Wong PS, Cheung A, Basher Z. Marine biogeographic realms and species endemicity. BioScience. (to appear).

22. Ready J, Kaschner K, South AB, Eastwood PD, Rees T, Rius J, Agbayani E, Kullander S, Froese R. Predicting the distributions of marine organisms at the global scale. Ecol Model. 2010;221(3):467-78.

23. Byers JE, McDowell WG, Dodd SR, Haynie RS, Pintor LM, Wilde SB. Climate and $\mathrm{pH}$ predict the potential range of the invasive apple snail (Pomacea insularum) in the Southeastern United States. PLOS ONE. 2013:8(2):e56812.

24. Lewin J, Eckman JE, Ware GN. Blooms of surf-zone diatoms along the coast of the Olympic Peninsula, Washington. XI. Regeneration of ammonium in the surf environment by the Pacific razor clam Siliqua patula. Mar Biol. 1979:52(1):1-9.

25. da Costa F, Martínez-Patiño D. Culture potential of the razor clam Solen marginatus (Pennánt, 1777). Aquaculture. 2009;288(1-2):57-64.
26. Remacha-Triviño A, Anadón N. Reproductive cycle of the razor clam Solen marginatus (Pulteney 1799) in Spain: a comparative study in three different locations. J Shellfish Res. 2006;25(3):869-76.

27. Abrahão JR, Cardoso RS, Yokoyama LQ, Amaral ACZ. Population biology and secondary production of the stout razor clam Tagelus plebeius (Bivalvia, Solecurtidae) on a sandflat in southeastern Brazil. Zoologia (Curitiba). 2010;27:54-64

28. Saeedi H, Kamrani E, Matsuoka K. Catastrophic impact of red tides of Cochlodinium polykrikoides on razor clam Solen dactylus in coastal waters of northern Persian Gulf. J Persian Gulf (Mar Sci). 2011;2(6):13-20.

29. da Costa F, Nóvoa S, Ojea J, Martínez-Patiño D. Changes in biochemical and fatty acid composition of the razor clam Solen marginatus (Solenidae: Bivalvia) during larval development. Mar Biol. 2011;158(8):1829-40.

30. Trainer VL, Cochlan WP, Erickson A, Bill BD, Cox FH, Borchert JA, Lefebvre KA. Recent domoic acid closures of shellfish harvest areas in Washington State inland waterways. Harmful Algae. 2007;6(3):449-59.

31. Hmida L, Ayache N, Haouas Z, Romdhane MS. Oocyte cohort analysis: criteria for an evaluation of the reproductive cycle in Solen marginatus (Pennánt, 1777), (Bivalvia: Solenacea) in Southern Tunisia. J Shellfish Res. 2010;29(1):129-34.

32. Lomovasky BJ, Gutiérrez JL, Iribarne OO. Identifying repaired shell damage and abnormal calcification in the stout razor clam Tagelus plebeius as a tool to investigate its ecological interactions. I Sea Res. 2005;54(2):163-75.

33. Basher Z, Costello MJ, Bowden DA. Global marine environment dataset (GMED). World Wide Web electronic publication. Version 1.0 (Rev.01.2014) http://gmed.auckland.ac.nz. Accessed 2014-05-12.

34. Fautin DG, Malarky L, Soberón J. Latitudinal diversity of sea anemones (Cnidaria: Actiniaria). Biol Bull. 2013;224(2):89-98.

35. Merow C, Smith MJ, Silander JA. A practical guide to MaxEnt for modeling species'distributions: what it does, and why inputs and settings matter. Ecography. 2013;36(10):1058-69.

36. Basher Z, Bowden DA, Costello MJ. Diversity and distribution of deep-sea shrimps in the Ross sea region of Antarctica. PLoS ONE. 2014;9(7):e103195.

37. Phillips SJ, Dudík M. Modeling of species distributions with Maxent: new extensions and a comprehensive evaluation. Ecography. 2008;31(2):161-75

38. Cordellier M, Pfenninger M. Inferring the past to predict the future: climate modelling predictions and phylogeography for the freshwater gastropod Radix balthica (Pulmonata, Basommatophora). Mol Ecol. 2009;18(3):534-44.

39. Pineda $\mathrm{E}$, Lobo JM. The performance of range maps and species distribution models representing the geographic variation of species richness at different resolutions. Glob Ecol Biogeogr. 2012;21(9):935-44.

40. Basher Z, Costello MJ. The past, present and future distribution of a deepsea shrimp in the Southern Ocean. PeerJ. 2016:4:e1713.

41. Franklin J. Mapping species distributions spatial inference and prediction/ Janet Franklin with contributions by Jennifer A. Miller. In: Miller JA (ed) Cambridge: Cambridge University Press; 2009.

42. Slater $\mathrm{H}$, Michael E. Predicting the current and future potential distributions of Lymphatic filariasis in Africa using Maximum Entropy ecological niche modelling. PLoS ONE. 2012;7(2):e32202.

43. Elsäßer B, Fariñas-Franco JM, Wilson CD, Kregting L, Roberts D. Identifying optimal sites for natural recovery and restoration of impacted biogenic habitats in a special area of conservation using hydrodynamic and habitat suitability modelling. J Sea Res. 2013;77:11-21.

44. Oliveira MH, Calheiros SK, Jacobi CM, Latini RO. Modeling the potential distribution of the invasive golden mussel Limnoperna fortunei in the Upper Paraguay River system using limnological variables. Braz J Biol. 2010;70(3):831-40.

45. Dudík M, Schaapire SJ, Phillips SJ. Correcting sample selection bias in maximum entropy density estimation. Adv Neural Inf Process Syst. 2006;18:323-30.

46. Phillips SJ. A brief tutorial on Maxent, versions: 3.3.1. http://www. cs.princeton.edu/ schapire/maxent/on. Accessed 2016-07-26.

47. Kinlan BP, Gaines SD. Propagule dispersal in marine and terrestrial environments: a community perspective. Ecology. 2003;84(8):2007-20.

48. Gaines SD, Gaylord B, Gerber LR, Hastings A, Kinlan B. Connecting places: the ecological consequences of dispersal in the sea. Oceanography. 2007:20(3):90-9. 
49. Barrows TT, Juggins S. Sea-surface temperatures around the Australasian margin and Indian Ocean during the Last Glacial Maximum. Quat Sci Rev. 2005;24:1017-47.

50. Raybaud V, Beaugrand G, Dewarumez JM, Luczak C. Climate-induced range shifts of the American jackknife clam Ensis directus in Europe. Biol Invasions. 2015;17(2):725-41.

51. Nickerson RB. A critical analysis of some razor clam (Siliqua patula Dixon) populations in Alaska. Juneau: Alaska Department of Fish and Game; 1975.
52. Johnson JE, Holbrook NJ. Adaptation of Australia's marine ecosystems to climate change: using science to inform conservation management. Int J Ecol. 2014;2014:1-12.

53. Rv Cosel. Three new species of Solen (Bivalvia: Solenidae) from the Indian Ocean, with remarks on the Solenidae of Madagascar. J Conchol. 1989;33(4):189-208.

\section{Submit your next manuscript to BioMed Central and we will help you at every step:}

- We accept pre-submission inquiries

- Our selector tool helps you to find the most relevant journal

- We provide round the clock customer support

- Convenient online submission

- Thorough peer review

- Inclusion in PubMed and all major indexing services

- Maximum visibility for your research

Submit your manuscript at

www.biomedcentral.com/submit 